\title{
Articles
}

\section{Joshua Marshman and the First Chinese Book Printed with Movable Metal Type}

\author{
MA Min*
}

\begin{abstract}
In 1998 in an essay published in Lishi yanjiu, I once discussed the pioneering efforts of Joshua Marshman and Joannes Lassar in the early nineteenth century to produce a Chinese translation of the Bible in Serampore, India. In this essay I mentioned that the Gospel of John 若翰所書之福音, translated and printed by Marshman and Lassar in 1813, "was in fact the first Chinese book printed using movable metal type."1 Today, fifteen years later, I have not yet seen any new discoveries requiring that I revise my assertions, and recently I had an opportunity to visit Serampore, to inspect what remains of the old Mission Press, and to collect some books and materials preserved there. This experience greatly enhanced my understanding of this episode of history. Hence, here I would like to use the materials I have at hand to discuss in more detail the early Chinese books printed with movable metal type and the achievements of the missionaries at Serampore in printing Chinese.
\end{abstract}

\section{A Review of Previous Findings}

At the end of the sixteenth century, modern Western printing technology spread to China-about this there is no dispute. But when were Chinese books first printed using movable metal type? It is here that we find inaccuracies.

It is often held that printing Chinese books with movable metal type began with Robert Morrison. For example, Zhang Shudong et al., in their General History of Chinese Printing, assert, "Robert Morrison (1782-1834), a member of the London Missionary Society, was the first Protestant missionary who entered China to propagate Christianity and who brought with him the means for making modern movable metal type." And in their chronology of major

* The Third President of the Society; Professor and President of Central China Normal University.

1 Ma Min 马敏, “Maximan, Lasha yu zaoqi de 'Shengjing' Zhongyi” 马希曼、拉沙与早 期的《圣经》中译 (Marshman, Lassar, and the Translation of the Bible into Chinese), Lishi yanjiu 历史研究 1998, no. 4. 
events, they write,

1814: Robert Morrison establishes a press in Malacca.

1815, August 5: Cha shisu meiyue tongji zhuan 察世俗每月統紀傳 (Chinese Monthly Magazine), the first modern periodical in Chinese, began publication.

1815: The British printer P. P. Thomas cuts movable metal type and begins printing Morrison's Dictionary of the Chinese Language in Macau. "This is the first time that Western movable-metal-type printing technology was used to compose and print a Chinese book within China's borders."

1819: The press in Malacca established by Morrison et al. uses Chinese movable metal type to print the first Chinese Old and New Testament Bible. $^{2}$

Xiong Yuezhi, in his Dissemination of Western Learning and Late Qing Society, writes that in 1822 the British printer P. P. Thomas "used printing equipment with Chinese movable type to print [Robert Morrison's] Dictionary of the Chinese Language 華英字典."3

Zhang Xiumin, in his History of Printing in China (vol.2), provides us with the following facts: Robert Morrison compiled his Dictionary of the Chinese Language in Macau, and the East India Company agreed to publish it. The printer P. P. Thomas then traveled from London to China around 1814, bringing with him printing equipment, movable type, and other necessary materials. After he arrived, several Chinese character engravers started the tedious task of cutting movable type on tin-alloy slugs. From 1815 to 1822 this team printed 600 copies of the six-volume dictionary at a cost of 12,000 British pounds. But to produce the movable type, the printers used the traditional Chinese method of cutting, and not the Western method of casting. ${ }^{4}$

Wan Qiying, in his History of China's Modern Printing Industry, notes that an English work, Joshua Marshman's Elements of Chinese Grammar 中 国言法, was printed in Serampore in 1814. In this book, which includes the original and a translation of Daxue 大學 (The Great Learning) as an appendix,

2 Zhang Shudong 张树栋 et al., Zhonghua yinshua tongshi 中华印刷通史 (A General History of Chinese Printing) (Beijing: Yinshua Gongye Chubanshe, 1999), pp.426, 996.

3 Xiong Yuezhi 熊月之, Xixue dong jian yu wan Qing shehui 西学东渐与晚清社会 (The Dissemination of Western Learning and Late Qing Society) (Shanghai: Shanghai Renmin Chubanshe, 1994), p. 121.

4 Zhang Xiumin 张秀民, Zhongguo yinshua shi 中国印刷史 (A History of Printing in China) (Hangzhou: Zhejiang Guji Chubanshe, 2006), vol.2, p. 445. 
the characters appear to have been printed with movable metal type. ${ }^{5}$ And Fan Muhan as well, in his Modern History of Printing in China, mentions that before Robert Morrison published his dictionary in Macau from 1815 to 1823, Joshua Marshman (1768-1837), an English Baptist missionary, had already published his Elements of Chinese Grammar in Serampore in $1814 .{ }^{6}$

A chronology of major events in the field of publishing in China states that in 1819 Robert Morrison, at his press in Malacca, published 新舊約中文 聖經 (The Old and New Testaments of the Bible, in Chinese), the first Chinese edition of the Bible and also the first Chinese book printed with movable metal type. ${ }^{7}$

And finally, Wu Min, in his History of Modern and Contemporary Printing in China, presents the following view:

Western missionaries were the first to introduce Western movable metal type and copper matrices to China. In 1807 the English missionary Robert Morrison arrived in Macau, where he translated the New Testament into Chinese. He also recruited Cai Gao 蔡高 and other character engravers to cast type and print in Guangzhou, but the local authorities prevented him from proceeding. He then transferred the operation to Malacca, where his team engraved copper matrices, cast type, composed type, and in 1819 printed the New Testament in Chinese. From what we know, this was the first Chinese book printed with movable metal type. ${ }^{8}$

The views above all differ in particular matters. But whatever date they offer for the first Chinese book printed with movable metal type- be it 1814, 1815, 1819, or 1822 - they are all later than 1813, when Joshua Marshman, in Serampore, printed the Gospel of John in Chinese using movable metal type.

Because of all this confusion, it is all the more important to delve into and clarify this significant bit of history.

5 Wan Qiying 万启盈, Zhongguo jindai yinshua gongye shi 中国近代印刷工业史 (A History of China's Modern Printing Industry) (Shanghai: Shanghai Renmin Chubanshe, 2012), pp. 11-12.

6 Fan Muhan 范慕韩, ed., Zhongguo yinshua jindai shi 中国印刷近代史 (A Modern History of Printing in China) (Beijing: Yinshua Gongye Chubanshe, 1995), p. 69.

7 Fang Ming 方鸣, compiler, Jinxiandai Zhongguo chuban shi dashi biannian 近现代中 国出版史大事编年 (A Chronology of Major Events in the Modern and Contemporary History of Publishing in China), Zhongguo chuban 中国出版 1991, no. 2.

$8 \mathrm{Wu}$ Min 伍敏, Zhongguo jinxiandai yinshua shi 中国近现代印刷史 (A History of Modern and Contemporary Printing in China) (Beijing: Zhongguo Da Baikequanshu Chubanshe, 1993). 


\section{The Baptist Missionary Press at Serampore}

In 1792 the Baptist Church in Britain established its own Baptist Missionary Society, the first protestant missionary organization in Europe and America. In November 1793 William Carey, one of the founders of this missionary society, and John Thomas, a missionary, arrived in Calcutta, India, to spread the gospel. Thus began the nineteenth-century Protestant missionary movement that spread throughout the world.

Because the Baptist Church was separate from the Anglican Church, the official Church of England, the English colonial authorities in India forbade the Baptists to proselytize in Calcutta. Having no alternative, Carey moved to Mudnabatty, about thirty miles north of Malda, where he undertook the superintendence over an indigo factory. Only after the Baptist Church sent follow-on missionaries like Joshua Marshman and William Ward, etc. to India in 1799, who went to the Danish colonial settlement at Serampore without any stay in Calcutta, did the missionary work begin and later it was joined by Carey and his family. Thus they all together established the mission post at Serampore.

At the Serampore mission post, the missionaries opened up a boarding school to support themselves and also established a press to publish a translation of the Bible. Carey thought that they should open and run a press (1) to help the missionaries support themselves and also to expand their interactions with the society, (2) to publish and distribute translations of the Bible in the languages of the East, and (3) to provide jobs for local converts to Christianity. ${ }^{9}$ Carey, Marshman, and Ward divided up the work. Carey oversaw translating the Bible into the various dialects of India. Marshman, who once served as a primary school teacher, managed the boarding school. And Ward, who had experience in printing, ran the press. Under Ward's supervision, the press, after its formal establishment in 1800, developed steadily. From 1801, when it published a Bengali translation of the New Testament, to 1832, the Mission Press at Serampore published over 210,000 volumes of religious and secular works in forty different languages. Its most remarkable accomplishment was that it cut character punches and then the matrices to cast the movable metal type for numerous native Indian languages and Chinese, thereby showing that it was possible to use this modern Western metal-type technology for printing books in the languages of the East.

To realize the ambitious plan that the Serampore mission post set for itself in 1804 of translating the Bible into all the languages of the East, Marshman and his son in 1805 began studying Chinese under Joannes Lassar, and in the

9 Sunil Kumar Chatterjee, William Carey and Serampore, 2nd enl. ed. (Serampore, 2004), p. 168. 
same year Marshman explored how the Mission Press might begin printing Chinese.

Chinese printing at Serampore passed through several stages of development. The first was when, in 1806, the press printed sample pages of Genesis and the Gospel of Matthew using carved woodblocks, but this was nothing more than a trial run. Then from around 1808 the press hired a Chinese man at a salary of 4 pounds per month to supervise Bengal natives carving Chinese movable wooden type (each character measuring 1.6 to 1.8 centimeters square), in order to print The Works of Confucius, which included passages from the Analects along with Marshman's translations into English. This involved carving the entire Analects, cutting the blocks into columns of text, composing the Chinese wooden type with the metal type of the English translation, and then printing. Published in 1809, The Works of Confucius consisted of chapters 1 to 9 of the Analects, with the original text, Marshman's English translation, and annotations. ${ }^{10}$ This was the first detailed English introduction to the Analects since the days of the Catholic missionaries in the late Ming and early Qing dynasties. Because the Chinese movable wooden type was large and the white space around the English metal type was generous, this quarto-size book ended up with 725 pages. $^{11}$

As the fruit of his study of Chinese, Marshman in 1809 wrote and published Dissertation on the Characters and Sounds of the Chinese Language. The movable wooden type used for the Chinese characters in this work were rather small. It seems that a complete woodblock was carved and then cut into individual characters, in contrast to the columns of Chinese text used for composing with large characters. ${ }^{12}$ This method of cutting woodblocks to produce small characters in movable wooden type was also used to supply type for uncommon characters when printing the Chinese translation of the Bible.

Because the size of Chinese movable wooden type was so large, printing with such type consumed lots of paper, and since such type broke easily, the type often had to be re-carved. Hence, Chinese movable wooden type was not very practical. For this reason, to print the earliest translations of books of the Bible, the Gospel of Matthew (1810) and the Gospel of Mark (1811), the Baptist Mission Press at Serampore used traditional woodblock printing technology, the same technology used by Robert Morrison at nearly the same time

10 Joshua Marshman, The Works of Confucius, vol. 1 (Serampore: Mission Press, 1809).

11 See Ma Min 1998, and Su Jing 蘇精, “Malisun yu Zhongwen yinshua chuban” 馬禮 遜與中文印刷出版 (Robert Morrison and the Printing and Publishing of Chinese) (Taipei: Taiwan Xuesheng Shuju, 2000), p. 144.

12 Joshua Marshman, Dissertation on the Characters and sounds of the Chinese Language (Serampore: Mission Press, 1809). 
in Guangzhou to secretly print Acts of the Apostles. Around 1811 the missionaries at Serampore thought of using Western metal-type technology to cast Chinese metal type. Relying on local craftsmen under the guidance of several Chinese men, the missionaries produced two plates of Chinese movable metal type. On one plate, the characters were 0.8 centimeters square, and on the other plate, the characters were 0.5 centimeters square, much smaller than the Chinese movable wooden type used for The Works of Confucius. But the Chinese sorts cast were all for commonly used characters; uncommon characters were still manually carved. ${ }^{13}$ In a relatively short space of time, the Mission Press at Serampore overcame many difficulties and made rapid progress. Earlier, in 1808, the missionaries-seeing how timeconsuming, troublesome, and expensive woodblock printing was-thought that printing the whole Bible in Chinese was a distant and impractical affair. ${ }^{14}$ But four years later, in 1812, they optimistically declared that the Mission Press was ready to use Chinese movable metal type to print the entire Bible in Chinese. ${ }^{15}$ Then during the night of March 11, 1812, a huge fire consumed the Mission Press at Serampore. While the press suffered a great lose, the punches and matrices of the languages of the East (including Chinese), accumulated with much effort, managed to survive with the result that the press could quickly resume its printing operations in these languages with movable metal type. ${ }^{16}$ A milestone achievement attesting this revival was that in 1813 it printed, for the first time using movable metal type, the Gospel of John, translated into Chinese by Joshua Marshman and Joannes Lassar.

\section{The Gospel of John, the First Chinese Book Printed with Western- Style Metal Type}

Prior to 1813, translations and publications of the Bible in Chinese by Protestant missionaries along the coast of China and at Serampore were all done using traditional Chinese woodblock printing, the time-honored method of Chinese book publishers for producing books (figure 1). In 1810 Robert Morrison published 耶穌救世使徒行傳真本, a Chinese translation of Acts of the Apostles, which he based on a manuscript that he brought with him from England, 四史敒编耶稣基利斯督福音之会编 (Harmony of the Gospels), a manu-

13 Su Jing 2000, p. 144.

14 Memoir Relative to the Translations of the Sacred Scriptures (Dunstable: J. W. Morris, 1808), p. 15.

15 Memoir Relative to the Translations of the Sacred Scriptures (Dunstable: J. W. Morris, 1812), p. 16.

16 John Clark Marshman, The Life and Times of Carey, Marshman, and Ward (1859; reprinted by the Council of Serampore College, 2005), vol.1, p. 469. 
script translation of a portion of the New Testament by Jean Basset (16621707), a French Jesuit missionary. Morrison's work was printed by woodblock and bound by a traditional string binding as a single volume, and it opens with a preface by Morrison. At present a copy is held by the Bible Society's Library at the University of Cambridge. The same year, at Serampore, Marshman and Lassar published a Chinese translation of the Gospel of Matthew titled 此嘉語由吇咷所著. For this book, 95 folios were printed by woodblock and bound by a traditional string binding into a single volume. In 1811, again at Serampore, they published a Chinese translation of the Gospel of Mark titled 此嘉音由咑嘞所著. Here 56 folios were printed by woodblock and bound by a traditional string binding into a single volume. In short, prior to 1813 the Serampore missionaries had yet to discover how to use Western movable-type printing technology to print Chinese books.

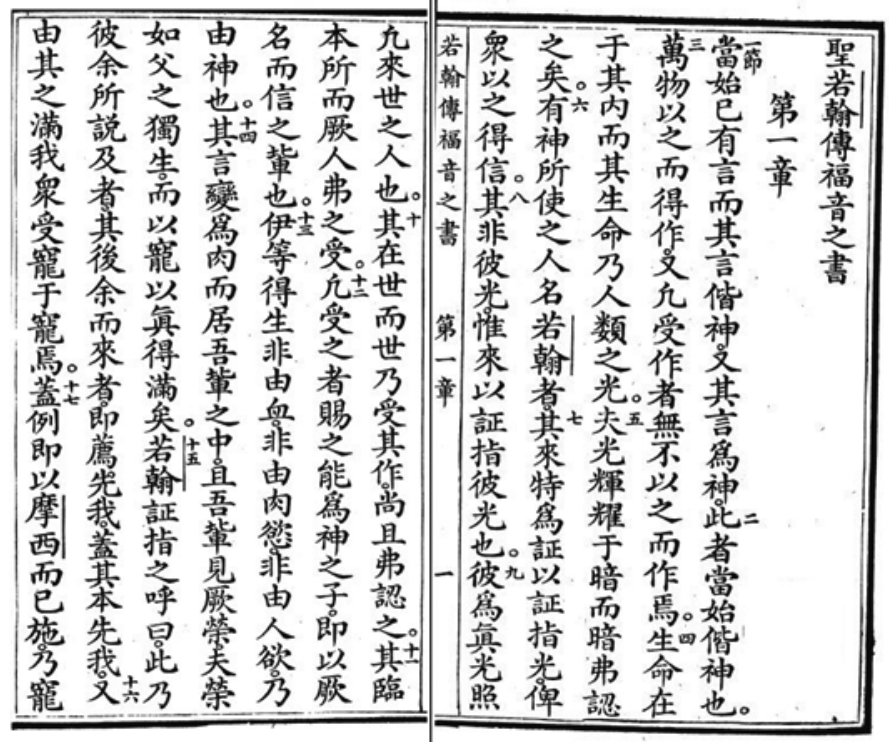

Figure 1 The opening pages of Robert Morrison's translation of the Gospel of John, printed with traditional woodblocks in 1813.

But 1813 was a turning point. For, as mentioned above, it was during this year that, after much exploration and many trials, the Mission Press at Serampore, under Marshman, finally succeeded in using Western movablemetal-type printing technology to print what was probably the first Chinese book printed with movable metal type, the Gospel of John 若翰所書之福音 (figure 2). 


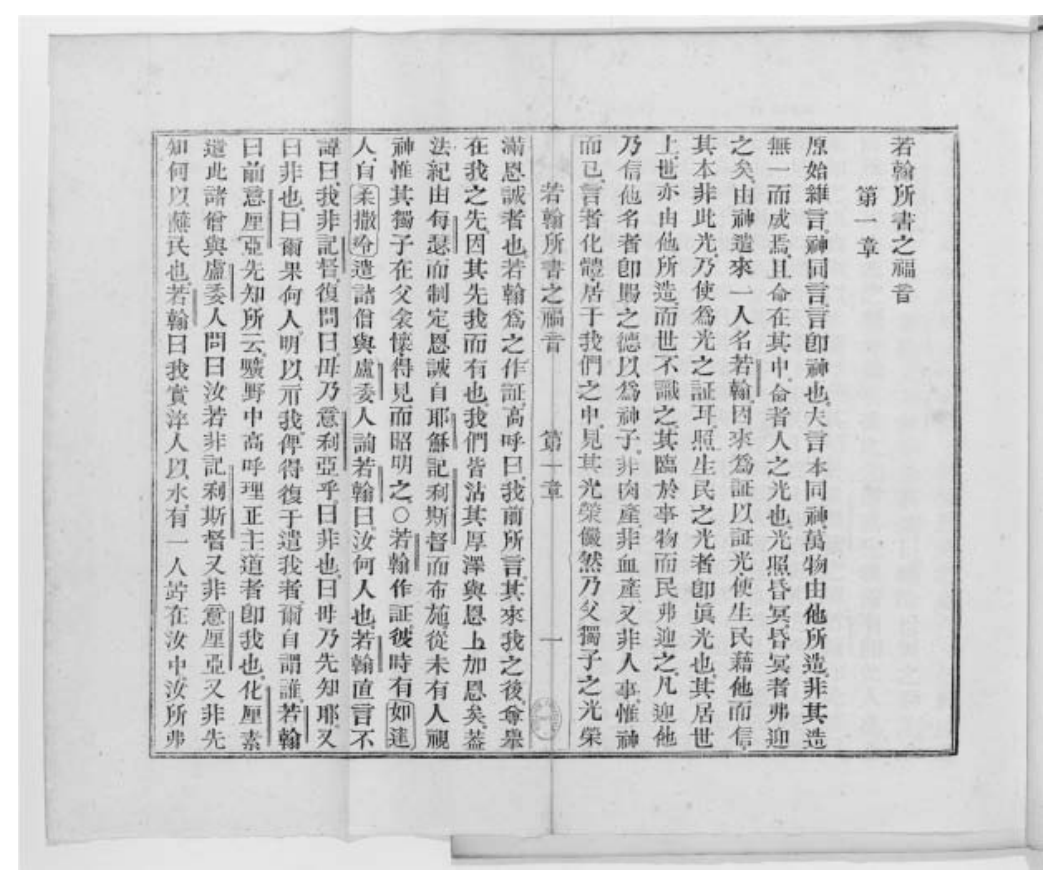

Figure 2 The opening pages of The Gospel of the Apostle John, printed with movable metal type at the Mission Press at Serampore in 1813.

I saw a copy of this translation of the Gospel of John in the Bible Society's Library at the University of Cambridge. Printed in 1813 at Serampore, this translation has 36 two-page folios printed with movable metal type, divided into 21 chapters, bound by a traditional string binding into one volume, and covered with a yellow wrapper. At the end of the volume were the three letters of John, but only 7 two-page folios of these letters remain. This library also has a copy of the 1814 reprint with the title 耶穌救世使徒若翰所書福音 (The Gospel of John, a Disciple of Jesus Christ), also with the three letters of John at the end. In addition, in the Angus Library of Regent's Park College at the University of Oxford, I saw another copy printed in 1813. This copy, of 72 folios divided into 21 chapters and printed with movable metal type, was bound in the Western style in one volume and has the English title The Gospel of the Apostle John. Both the printing and the binding were finely done.

Marshman thought that a remarkable achievement of the Baptist Mission Press at Serampore was that it could use movable metal type to print Chinese translations of the Bible. He thought that movable metal type was not only attractive, clear, and durable, but also more convenient than traditional woodblock printing, for it permitted insertions and deletions, allowed multiple printings and large print runs, and was low-cost and much less expensive than 
woodblock printing. ${ }^{17}$ According to Marshman's calculations, printing with movable metal type saved about two-thirds of the cost of traditional woodblock printing. ${ }^{18}$

Marshman also pointed out that if the same Biblical text were printed at Serampore using movable metal type and woodblock printing, the cost of printing with movable metal type, from the casting of type to the finished pages, would be only one quarter of that of woodblock printing, and that if one compares printing with metal type at Serampore with Morrison's printing of Biblical texts by woodblock in China, the former method costs only a third of the latter method. ${ }^{19}$

On the significance of Marshman's using movable metal type to print Chinese materials, John Clark Marshman, Marshman's son, had this to say in his Life and Times of Carey, Marshman, and Ward:

This [printing with movable metal type] is one of the most memorable improvements made in Chinese printing since its invention, twenty centuries ago; not only because it admits of the revision of a work as it passes through the press, but also on the ground of economy.... This improvement, which originated, and was, to a considerable extent, matured at Serampore, before it was taken up by other missionary bodies, forms an era in the history of Chinese literature; and it will, doubtless, be adopted by the Chinese themselves, when their stationary civilisation, of which the block printing is a very apt emblem, begins to yield to the impulse of European improvement. ${ }^{20}$

According to John Clark Marshman, in producing metal type, the Mission Press at first had assistance from local craftsmen. But only after John Lawson, missionary and printer, joined the Serampore Mission in 1812 did the press started producing fine, practical type. Early on, in 1807, Marshman wrote a letter to the London headquarters of the Baptist Church asking for Lawson's help in the efforts of the press at Serampore at printing Chinese. In 1811, after he was baptized and became a member of the Baptist Church, Lawson, together with his wife and several missionaries, went first to Calcutta, where he stayed nearly a year owing to a series of setbacks before he finally obtained permission to proceed to the mission at Serampore. His arrival at Serampore led to a breakthrough at the Mission Press in the development of Chinese printing with movable metal type, opening the way for it

17 A Memoir of the Serampore Translations for 1813 (Kettering: J. G. Fuller, 1815), pp. $16-17$.

18 Letter from Dr. Marshman to Dr. Ryland, December 1813.

19 A Memoir of the Serampore Translations for 1813. Quoted in Su Jing 2000, p. 145.

20 John Clark Marshman 1859/2005, vol. 2, pp.63-64. 
to print large quantities of Chinese books. ${ }^{21}$

There were two ways of making Chinese movable type. One way was to make individual Chinese movable type as needed. This way involved one of two methods. Either an artisan would cut movable type on a slug of a lead and tin alloy, as the British printer P. P. Thomas did in Macau in 1815.22 Or the printer would use a Chinese woodblock to cast a metal plate, which would then be cut into individual pieces of Chinese type, as the British missionary Samuel Dyer did in about 1833 in his early attempt to produce Chinese type in Malacca. The other way of producing Chinese type was first to produce character matrices, from which the printer casts movable type. Here too there were two methods for doing this. Either the artisan would cut intaglio regular-character matrices to cast type, as the German missionary Karl Gützlaff did on copper plates for 4,000 characters, which were then sent to Serampore for casting type - an effort that did not reach fruition. Or the artisan would cut high-raised, character mirror images on steel punches, which were then used to punch intaglio characters in copper-alloy matrices, and these matrices were in turn used to cast movable metal type. ${ }^{23}$ For example, Dyer, later in his career, primarily used this method to make steel movable type. Before his death, he cut 1,845 pieces of large type and some pieces of small type. In 1833 the Chinese Repository reported that someone in India (quite possibly Serampore) cast Chinese movable metal type, perhaps by using steel punches and matrices. ${ }^{24}$

We lack explicit statements of the method that the Baptist missionaries at Serampore used to produce metal type. But from the terms used in sundry scattered sources, we can infer that in the first stage of adoption, artisans were probably cutting type on slugs of a lead and tin alloy, as Thomas did, and that in the second stage of adoption, artisans had developed stamping technology, as indicated by the appearance of terms like "punch" and "matrix" in our sources. Hence, artisans working in the Western tradition were no longer cutting characters, like their Chinese counterparts, carving woodblocks. Rather, they adapted the Western method of casting type (a point that requires further evidence).

21 John Clark Marshman 1859/2005, vol. 2, p. 63.

22 There is insufficient evidence to support He Shengnai's claim that Thoms, at Marshman's request, went to Macau to "cut character matrices and cast Chinese type” (Zhuang Yu 莊俞 and He Shengnai 賀聖儡, eds., Zuijin sanshiwu nian zhi Zhongguo jiaoyu 最近三十五年之中國教育 [Education in China in the Last Thirty-five Years] [Shanghai: Shangwuyin Shuguan, 1931]).

23 See Su Jing 2000, p. 4.

24 See Fan Muhan 1995, pp.65-69. 


\section{The Printing of Chinese after 1813}

The Mission Press at Serampore, after establishing a method for printing Chinese using movable metal type and printing the Gospel of John and the three letters of John in Chinese, printed a number of other Chinese works with movable metal type in rapid succession.

In 1814 the Mission Press printed and published Marshman's Elements of Chinese Grammar, an English work on Chinese grammar. This systematic study of Chinese presents the system of writing, pronunciation, and grammar of the language, and appears to be the earliest work in English on Chinese grammar. ${ }^{25}$ It is worth noting that though this book was written in English, it quotes as examples a considerable amount of Chinese from the Chinese classics, including the Four Books, the Five Classics, and Zhu Xi's Sishu zhangju $j i z h u$ 四書章句集注 (Collected Annotations of the Four Books). These example sentences were printed with metal type and inserted in the English text. Appended at the end of Elements of Chinese Grammar is Daxue 大學 (The Great Learning) in the original, along with an English translation done by Marshman's son, John Clark Marshman, and reviewed by Marshman himself. This bilingual work has attached to it an explanation of the characters. Hence, though this is an English work, we can regard it as an example of Chinese printing in our analysis.

In 1815, a year after the appearance of Elements of Chinese Grammar, the Mission Press at Serampore published an important work in the history of missionary activity in China, Robert Morrison's Grammar of the Chinese Language. ${ }^{26}$ Like Marshman, Morrison used English grammatical analysis to analyze Chinese grammar. The book covers pronunciation, nouns, numbers, pronouns, verbs, adverbs, prepositions, conjunctions, and interjections, as well as provincial dialects, syntax, and prosody at the end. Morrison covers Chinese verbs in particular detail, devoting a third of the book to the topic. In this book many Chinese examples are printed alongside their English translations, and the Chinese is printed with fine movable metal type. The fact that Marshman's and Morrison's Chinese grammars were published at nearly the same time has led scholars to wonder whether Marshman, in his Elements of Chinese Grammar, borrowed from Morrison's Grammar of the Chinese Language. But in fact, Marshman and Morrison each maintained his own point of view, even to the point of engaging in intense rivalry. In my view

25 Joshua Marshman, Elements of Chinese Grammar (Serampore: Mission Press, 1814). This work, often called Clavis Sinica, has a total of more than 600 pages. Since it was published a year earlier than Robert Morrison's Grammar of the Chinese Language, it is considered the first Chinese grammar in English.

26 Robert Morrison, A Grammar of the Chinese Language (Serampore: Mission Press, 1815). 
and from the evidence I have seen, though Morrison had finished his manuscript in 1811 and publication was delayed in India till 1815, and though Marshman was responsible for publishing Morrison's grammar, Marshman did not borrow from Morrison, and there were reasons for the delay. ${ }^{27}$ The relevant point here is that in 1812 the British Select Committee at the Factory at Canton (that is, the governing board of the Guangdong office of the British East India Company) recommended that Morrison publish his Grammar of the Chinese Language in far away India because the Mission Press at Serampore had already succeeded in using movable metal type to print Chinese at a basic level and had applied this technology to printing the Chinese Bible and related Chinese books.

After 1815 the Mission Press entered a highly productive period in translating the Bible into Chinese and printing and publishing this work. In the following years it printed in Chinese several books of the Bible and ultimately the whole Bible: ${ }^{28}$

1815-1822 The New Testament, printed with movable metal type and bound by a traditional string binding in one volume, from the Gospel of Matthew 使 徒馬寶傳福音書 to Revelation 若翰顯示之書.

1816 Genesis 神造萬物書, printed with movable metal type and bound by a Western hardcover binding in one volume.

1817-1821 The Old Testament, printed with movable metal type and bound by a traditional string binding in four volumes. Genesis to Deuteronomy 摩西 復示律書 was printed in 1817; Job 若百書 to the Song of Solomon 所羅門之詩 歌 in 1818; and Isaiah 先知以賽亞之書 to Esther 依士得耳之書 in $1821 .{ }^{29}$

1822 The Bible, printed with movable metal type and bound by a Western hardcover binding in two volumes. Volume 1 contains Genesis to Esther, and volume 2 contains Job to Revelation. This was the first complete Bible published in Chinese.

1823 Genesis and the other books of the Bible 神造萬物書與以至百多書, a

27 For a detailed analysis, see Ma Min 马钽, "Yufa shu: Maximan shifou chaoxi Malixun-19 shiji chu zaoqi Yingguo chuanjiaoshi zhi jian de yi chang zhenglun" 语法书：马希曼是否抄袭马礼逊？-19 世纪初早期英国传教士之间的一场争论 (In His Grammar, Did Marshman Copy Morrison? A Controversy over Two British Missionaries in the Early Nineteenth Century), in Tao Feiya 陶飞亚 and Liang Yuansheng 梁元生, eds., Dongya Jidujiao zai quanshi 东亚基督教再诠释 (Hong Kong: Zhongwen Daxue Chubanshe, 2004).

28 I compiled the following list from works that I found in the Angus Library of Regent's Park College at the University of Oxford.

29 The most detailed account of missionaries' translation and publication of the Bible in Chinese before 1830 can be found in "Chinese Version of the Bible," Chinese Repository 4 (1835), no. 6. 
revised version, printed with movable metal type and bound by a Western hardcover binding in one volume.

\section{The Importance and Legacy of Chinese Printing at the Mission Press}

From the nineteenth century, Western movable-metal-type printing technology, first developed by Johannes Gutenberg, continuously entered China and began to affect the traditional woodblock-printing industry. There were several sources from which Western printing technology penetrated China. One was the early attempt at printing Chinese with movable metal type by Marshman and others at the Baptist Mission Press in Serampore. Others were the continuing efforts of Morrison, Thomas, William Milne, John Robert Morrison (son of Robert Morrison), and Dyer of the London Missionary Society at Macau, Malacca, Penang Island in Malaysia, and Singapore. Though the Chinese type that Dyer produced became the main font of the modern China printing market, and though his method for cutting Chinese type has been passed down, it was the Baptist missionaries at Serampore who first introduced printing with movable metal type to China.

In fact, the influence of the missionaries at Serampore was not as some scholars imagine it. Because Marshman and other missionaries were printing Chinese in far off India, their influence on modern Chinese printing technology was quite limited. Rather, the printing achievements of the Serampore missionaries influenced missionaries in China through frequent correspondence among missionaries and continuous communication among missionary societies.

Let me first make one point clear. Thought the missionaries at Serampore engaged in printing Chinese with movable metal type only for a short while, their total print volumes and the areas over which their print materials were distributed were much more significant than previously thought. For example, Morrison's Grammar of the Chinese Language had a first printing in 1815 of 500 copies, most of which ended up in China. To give another example, when in 1822 Marshman and his colleagues printed the first Chinese Bible using movable metal type, they printed 1,600 sets of the Old Testament and 3,000 sets of the New Testament. ${ }^{30}$ This was followed by frequent reprintings of either the whole Bible or portions of it. Many of these Chinese Bibles printed by the Mission Press at Serampore found their way to Southeast Asia and China and had a definite influence on churches in China, especially Baptist missions in China, which used the translation by Marshman and Lassar over

30 "Brief Review of the Translation and Printing of the Sacred Scriptures by the Serampore Brethren," 1824. 
a long period. In 1843, when Protestant missionaries in China met in Hong Kong to discuss translating an authoritative version of the Bible, the Delegates Version, the translation by Marshman and Lassar was listed as an important reference translation.

Next, we must also look at the important influence that Marshman's printing with movable metal type at Serampore exerted on Morrison's notions of printing.

Like the Catholic Jesuit missionaries before him, Morrison, after he arrived in China in 1807, greatly appreciated traditional Chinese woodblock printing and thought that it was the most appropriate method for printing Chinese books, In fact, his early translations of portions of the Bible he had printed by woodblock. From 1811 he gradually came to know about the efforts of Marshman and his fellow missionaries at Serampore to print the Bible with movable metal type, and he received a sample printed with such type, but these efforts did not impress him. Only in 1815, when the board of directors of the London Missionary Society sent him a letter asking him to compare the advantages and disadvantages in China of printing with woodblocks versus printing with movable metal type, did Morrison begin to consider this issue in earnest, but his conclusion was that woodblock printing was far superior to movable-metal-type printing. In Morrison's view, woodblock printing had the following advantages:

- Woodblock printing requires less effort for composition and reduces the possibility of printer's errors.

- Carving characters in wood is cheaper than casting characters in type. Moreover, woodblocks stand up better to burnished woodblock printing than type stands up to letterpress printing.

- Woodblocks can be stored and used for reprinting.

- Characters printed with woodblocks can be printed evenly on thin Chinese paper. Characters thus printed are pleasing to the eye. Hence, woodblock printing is better suited to printing the Chinese classics. ${ }^{31}$

Morrison also criticized the missionaries at Serampore for stating that printing with movable metal type was much cheaper than printing with woodblocks, saying that their statements did not accord with the facts. He regarded with great distain their commercial self-promotion. ${ }^{32}$

However, from the mid-1820s Morrison had a change of attitude toward

31 See Su Jing 2000, pp. 14-15.

32 Archives of the London Missionary Society, South China, 1.4.B, Morrison to Burder, Canton, October 11, 1815. Quoted in Su Jing 2000, p. 146. 
printing with movable metal type. He no longer held that woodblock printing was the only way to print Chinese. Rather, he thought that casting movable metal type and using modern Western printing technology was the basic way to develop the Chinese printing industry, and he himself began to support and try out movable metal type for printing Chinese books. He even hoped that Britain would become the first country to produce Chinese movable metal type. ${ }^{33}$

Morrison's change of attitude had many reasons, but among them we must include the fact that through his long dispute with the missionaries at Serampore over the proper means of printing Chinese, he gradually experienced the state-of-the-art nature and convenience of printing with movable metal type. For example, in his Grammar of the Chinese Language, which he had printed at the Mission Press in Serampore, the characters in the text and on the cover are finely done and in no way inferior to characters produced by traditional Chinese woodblock printing. Though there is no clear record, Morrison must have had an opportunity to view a copy of the Chinese Bible printed with movable metal type at Serampore through many channels, especially through the British and Foreign Bible Society, which supported his efforts and those of Marshman to translate the Bible into Chinese over an extended period of time, and such a Bible must have left a deep impression on him. But Morrison did mention that he received the Chinese grammar book that Marshman had mailed to him, as well as portions of the Chinese Bible printed at Serampore and transmitted to him by a friend. Though Morrison withheld praise of the translation quality of these portions of the Chinese Bible, he had nothing negative to say about print quality. If I may venture a hypothesis, it may have been Morrison's secret desire to match and surpass the print quality of the Mission Press at Serampore at a site in China. Corroborating this view is the fact that he wholeheartedly advocated movable-metal-type printing late in his career, and the fact that he greatly supported the efforts of his son John Robert Morrison and his successor Samuel Dyer to print Chinese with movable metal type.

Hence, even though it was the missionaries of the London Missionary Society, including the pioneering Robert Morrison, who introduced Western printing with movable metal type to China, we must not forget the initial efforts of Joshua Marshman and other Baptist missionaries in far-off India. After all, history is the result of multiple efforts emanating from multiple sources. It is the responsibility of historians to objectively clarify the complexly intertwined and mutually influencing connections of history, and not only to discuss the successes and failures of the great men of history.

33 See Su Jing 2000, p. 16. 
